\title{
Activation-dependent learning rule for GPCR localization - 5ht2AR regulation in prefrontal cortical neurons
}

Gabriele Scheler

From Twenty Second Annual Computational Neuroscience Meeting: CNS*2013

Paris, France. 13-18 July 2013

Serotonin (5-ht) through 5ht2A receptors increases neuronal excitability (the neuronal gain function) by blocking voltage-gated $\mathrm{K}+$ channels (Kv1.5) [1]. 5ht2A receptors also reduce calcium influx and activate calcium from intracellular stores $(\mathrm{Ca}[\mathrm{i}])$ [2]. High agonist exposure generally decreases 5 ht $2 \mathrm{~A}$ density through endocytosis [3], in contrast 5 ht $2 \mathrm{~A}$ receptors are upregulated after 5-ht innervation loss or under low 5 ht exposure [4]. Both adaptations usually requires increase of $\mathrm{Ca}[\mathrm{i}]$ and/or PKC pathway activation. We want to understand the contribution of serotonin receptor and other GPCR regulation on neuronal plasticity by the differential expression level of these receptors and the conditions for their regulation. As a hypothesis to guide further research, we propose to use a learning rule for 5 ht $2 \mathrm{~A}$ placement, such that receptor density $(\mathrm{R})$ is decreased by high agonist, or increased by low agonist, but only in the presence of high internal calcium.

$$
\Delta \mathrm{R}=\mathrm{X}([5 \mathrm{ht}]-[5 \mathrm{ht}] \mathrm{m}) \gamma([\text { Cai }] /[\text { Cai }] \mathrm{m})
$$

Here [ $5 \mathrm{ht}] \mathrm{m}$ is the average $5 \mathrm{ht}$ concentration, [Cai]m the average calcium concentration, $5 \mathrm{ht}$ is the actual concentration, $\mathrm{x}$ and $\gamma$ are scaling factors. We further assume that [Cai] reflects the history of neuronal activation.

This learning rule may now be used in a network of model neurons. Principal neurons in prefrontal cortex (PFC) are initialized with a random distribution of 5 ht2A receptors linked to voltage-gated $\mathrm{K}+$ channels to regulate neuronal excitability. The model contains glial cells as variable sinks or sources of glutamate, to stabilize network activation, and a set of interneurons which

\footnotetext{
Correspondence: gscheler@gmail.com

Carl-Correns-Foundation, Mountain View, CA 94040, USA
}

contain activating 5ht2a receptors [5]. Synaptic connectivity is initially random.

The model is loaded with patterns which produce a characteristic recurrent neural representation, determined by the synaptic connectivity and the 5ht2A-regulated intrinsic gain functions [1]. The model is trained under $5 \mathrm{ht}$ stimulation of varying magnitudes. $5 \mathrm{ht}$ increases excitability of neurons in a dose-dependent manner, and the density of $5 \mathrm{ht} 2 \mathrm{~A}$ receptors affects the intrinsic gain functions. We can show that patterns that were learned under high serotonin contain neurons with decreased 5 ht sensitivity. When similar patterns are re-eoncountered under average or low serotonin conditions, these (the overlapping) features will be suppressed. Since the relevant neurons have decreased response to serotonin, they also have decreased excitability. The model could be altered to use dendritic regions rather than neurons. Since 5 ht memory affects neuronal excitability, we have intrinsically generated differences in firing rates that start to affect synaptic connectivity. This creates traces in synaptic connectivity independent of $5 \mathrm{ht}$ activation. If $5 \mathrm{ht} 2 \mathrm{AR}$ memory is erased, the trace is still present. Synaptic connectivity also determines which neurons (dendritic regions) receive sufficient input to undergo 5 ht-mediated plasticity. The transfer of memory between synaptic connectivity and G-protein coupled receptor (GPCR) localization is therefore a two-way process. Memory may be stored in different places at different times. The model is undoubtedly simplistic, since many co-regulations among GPCRs exist, which are cell-type specific and require detailed analysis. But it directly explains findings such as [6], where 5-HT2AR stimulation produces an increase in activity for preferred target locations and/or a reduction in activity for nonpreferred locations in a working 
memory task in PFC. Most importantly, it provides a unified starting point to understand the regulation of GPCR distribution as a method for pattern storage that is synergistic with but not identical to AMPA synaptic strengthening or weakening, and may play an as yet not well understood role in the maintenance of a synapse.

Published: 8 July 2013

\section{References}

1. Zhang ZW, Arsenault D: Gain modulation by serotonin in pyramidal neurones of the rat prefrontal cortex. J Physiol 2005, 566(Pt 2):379-94, Epub.

2. Day $\mathrm{M}$, et al: Stimulation of $5-\mathrm{HT}(2)$ receptors in prefrontal pyramidal neurons inhibits $\mathrm{Ca}(\mathrm{v}) 1.2 \mathrm{~L}$ type $\mathrm{Ca}(2+)$ currents via a PLCbeta/IP3/ calcineurin signaling cascade. J Neurophysio/ 2002, 87(5):2490-2504.

3. Raote I, Bhattacharya A, Panicker MM: Serotonin 2A (5-HT2A) Receptor Function: Ligand-Dependent Mechanisms and Pathways. CRC Press; 2007, chapter 6.

4. Kong XY, Wienecke J, Hultborn $H$, Zhang M: Robust upregulation of serotonin 2a receptors after chronic spinal transection of rats: an immunohistochemical study. Brain Res 2010, 1320:60-68.

5. Jakab RL, Goldman-Rakic PS: Segregation of serotonin 5-ht2a and 5-ht3 receptors in inhibitory circuits of the primate cerebral cortex. J Comp Neurol 2000, 417:337-348.

6. Williams GV, Rao SG, Goldman-Rakic PS: The physiological role of 5-HT2A receptors in working memory. J Neurosci 2002, 22(7):2843-54.

doi:10.1186/1471-2202-14-S1-P344

Cite this article as: Scheler: Activation-dependent learning rule for GPCR localization - 5ht2AR regulation in prefrontal cortical neurons. BMC Neuroscience 2013 14(Suppl 1):P344.

\section{Submit your next manuscript to BioMed Central and take full advantage of:}

- Convenient online submission

- Thorough peer review

- No space constraints or color figure charges

- Immediate publication on acceptance

- Inclusion in PubMed, CAS, Scopus and Google Scholar

- Research which is freely available for redistribution

Submit your manuscript at www.biomedcentral.com/submit
Biomed Central 